\title{
PENGUKURAN KINERJA KEUANGAN BANK MUAMALAT INDONESIA DENGAN \\ METODE SHARIA CONFORMITY AND PROFIT ABILITY (SCnP)
}

\author{
Evan Hamzah Muchtar, Mohamad Rofi \\ STAI Asy-Syukriyyah \\ evan.hamzah.m@gmail.com, rofimuhamad731@gmail.com
}

\begin{abstract}
PT Bank Muamalat Indonesia Tbk is the first Islamic bank in Indonesia which was established in 1991 and started operating in 1992. However,it's financial performance is not good, as evidence in early 2018 it will be acquired due to capital problems. Researchers are interested in conductingthis research with the aim to find out the financial performance of PT Bank Muamalat Indonesia Tbk in 2013-2017. This research is quantitative descriptive with SPSS 22 analysis tools. The research data is secondary data obtained from the annual report of Bank Muamalat Indosia from 2013 to 2017. The method used is SCnP (Sharia Conformity and Profitability) as measured by indicators sharia suitability and profitability. The results showedthat the performance of Bank Muamalat Indonesia during 2013-2017 was at the coordinates of $X=83.30$ and $Y=1.99$ with the position of Lower Left Quadrant (LLQ).
\end{abstract}

Keywords: Financial Performance, Sharia Conformity and Profitability.

\begin{abstract}
Abstrak: PT Bank Muamalat Indonesia Tbk adalah bank syariah pertama di Indonesia yang didirikan pada tahun 1991 dan mulai beroperasi pada tahun 1992. Namun demikian kinerja keuangannya kurang baik, terbukti pada awal tahun 2018 akan diakuisisi dikarenakan persoalan permodalan. Peneliti tertarik untuk melakukan penelitian ini dengan tujuan untuk mengetahui kinerja keuangan PT Bank Muamalat Indonesia Tbk tahun 20132017. Penelitian ini adalah penelitian deskriptif kuantitatif dengan alat analisis SPSS 22.Data penelitian berupa data sekunder yang diperoleh dari laporan tahunan (annual report) Bank Muamalat Indonesia dari tahun 2013 hingga 2017. Metode yang digunakan adalah Sharia Conformity and Profitability (SCnP) yang diukur dengan indikator kesesuaian syariah dan profitabilitas. Hasil penelitian menujukkanbahwa kinerja keuangan Bank Muamalat
\end{abstract}


Indonesia selama tahun 2013-2017 berada pada titik koordinat $\mathrm{X}$ $=83,30$ dan $\mathrm{Y}=1,99$ dengan posisi Lower Left Quadrant (LLQ).

\section{Keywords: Kinerja Keuangan, Sharia Conformity and Profitability}

\section{PENDAHULUAN}

Perbankan syariah adalah suatu sistem perbankan yang dikembangkan berdasarkan syariah Islam. Hukum bisnis syariah adalah keseluruhan dari peraturan-peraturan dan ketentuan-ketentuan hukum yang berkaitan dengan praktik bisnis secara syar'i atau sesuai dengan syariah, guna meningkatkan kesejahteraan dan kemaslahatan manusia. ${ }^{1}$ Bank syariah merupakan bank yang secara operasional berbeda dengan bank konvensional. Konsep dasar bank syariah didasarkan pada Al-Qur'an dan Hadits. Semua produk dan jasa yang ditawarkan tidak boleh bertentangan dengan isi Al-Qur'an dan Hadits Rasulullah SAW. ${ }^{2}$

Bank sebagai suatu lembaga yang berperan mengerahkan dana yang berasal dari masyarakat berupa simpanan dan menyalurkan dana tersebut kepada masyarakat yang berupa pinjaman. Bank juga sebagai industri yang dalam kegiatan usahanya mengandalkan kepercayaan masyarakat. Penilaian kinerja bank penting dilakukan, baik oleh manajemen, pemegang saham, pemerintah, atau pun pihak yang berkepentingan demi menjaga kepercayaan masyarakat terhadap bank tersebut. Dalam penilaian kinerja bank tersebut terdapat dalam laporan keuangan. Tujuan laporan keuangan pada sektor perbankan syariah adalah untuk menyediakan informasi yang menyangkut posisi keuangan, kinerja serta perubahan posisi keuangan, aktivitas operasi perbankan yang bermanfaat dalam pengambilan keputusan. ${ }^{3}$

Penilaian kinerja pada perbankan konvensional maupun syariah di Indonesia saat ini biasanya dilihat dari pengukuran kinerja keuangan dengan menggunakan rasio RGEC (Risk Profile, Good Coporate Governance, Earning and Capital). Apabila perbankan syariah hanya menggunakan pengukuran yang sama dengan perbankan konvensional untuk mengukur

\footnotetext{
1 Evan Hamzah Muchtar. Konsep Hukum Bisnis Syariah Dalam Al-Qur'an Surah AlBaqarah [2] Ayat 168-169 (Kajian Tematis Mencari Rezeki Halal). Ad-Deenar: Jurnal Ekonomi dan Bisnis Islam, 2 (2) 2018. 156.

${ }^{2}$ Ismail. Perbankan Syariah. (Jakarta: Kencana Prenada Group. 2011). 29.

3 Muhammad Suwiknyo Dwi. Akuntansi Perbankan Syariah. (Yogyakarta: Trust Media, 2009). 24.
} 
kinerjanya, maka akan terdapat ketidaksesuaian nilai dari penggunaan indikator kinerja perbankan konvensional dengan objek yang lebih luas yang terdapat pada perbankan syariah. ${ }^{4}$

Sejatinya, penelitian mengenai alat ukur yang telah disesuaikan dengan karakteristik perbankan syariah atau sesuai dengan tujuan syariah (maqashid syariah) telah ada. Beberapa penelitian telah berupaya untuk membuat alat ukur yang telah disesuaikan dengan konsep dan praktek perbankan syariah. Shahul Hameed pada 2004 memperkenalkan Islamicity Performance Index, selanjutnya Mohammed, Djulzastri dan Taib pada 2008 dengan Maqasid Index dan Kuppusamy pada tahun 2010 dengan metode Sharia Conformity and Profitability (SCnP) model. Seluruh hasil penelitian yang menggunakan alat ukur tersebut menunjukkan hasil yang lebih baik jika dibandingkan dengan mengukur menggunakan metode konvensional. Oleh sebab itu, penelitian ini akan mengukur kinerja perbankan syariah menggunakan metode yang telah disesuaikan dengan perbankan syariah, yakni metode Sharia Conformity and Profitability (SCnP) model. ${ }^{5}$

Adapun perbedaan yang mendasar pengukuran kinerja keuangan menggunakan Sharia Conformity and Profitability (SCnP) Model. Pertama, pengukuran metode Sharia Conformity and Profitability (SCnP) lebih komplek karena menggabungkan dua orientasi penilaian yang memang tidak dapat dipisahkan yaitu sisi kesyariahan suatu bank dan sisi financial bank tersebut. Kedua, dengan adanya penggabungan dua orientasi sosio-ekonomi pada Sharia Conformity and Profitability (SCnP) hasil dari pengukuran ini lebih efektif. Oleh karena itu pengukuran kinerja keuangan dengan metode Sharia Conformity and Profitability (SCnP) Model dapat dijadikan alternatif pengukuran kinerja keuangan bank umum syariah. ${ }^{6}$

PT Bank Muamalat Indonesia Tbk (Bank Muamalat) beberapa tahun terakhir diterpa isu yang tidak sedap, bank syariah pertama di Indonesia tersebut dinyatakan terancam bangkrut. Hal ini dikarenakan kondisi

\footnotetext{
4 Annisa Dina Aolia, Analisis Penilaian Kinerja Perbankan Syariah di Indonesia Menggunakan Metode RGEC dan Sharia Maqashid Index. Skripsi. (Jakarta: UIN Syarif Hidayatullah. 2017). 8.

5 Meri Diana Putri. Analisis Pengukuran Kinerja Keuangan Bank Umum Syariah di Indonesia Menggunakan Metode Sharia Conformity and Profitability (SCnP) Model, Skripsi (Lampung: UIN Raden Intan. 2018). 8-9.

${ }^{6}$ Lia Anggraeni Prasetyowati, Luqman Hakim Handoko. Pengukuran Kinerja Bank Umum Syariah dengan Maqasid Index dan Syariah Conformity And Profitability (SCnP). Jurnal Akuntansi Dan Keuangan Islam.4 (2) 2016. 109.
} 
keuangan Bank Muamalat sejak tahun 2015 mencatat kinerja yang tidak menyenangkan. Di sekitar September 2017, diberitakan bahwa Bank Muamalat sudah mendapatkan pembeli, yaitu PT Minna Padi Investama Sekuritas Tbk yang akan membeli bank ini. Bahkan PT Minna Padi sudah menandatangani perjanjian untuk mengambil saham dalam rangka Hak Memesan Efek Terlebih Dahulu (HMETD) sebagai pembeli siaga.Entah mengapa di awal Februari 2018, PT Minna Padi mengatakan tidak jadi menjadi 'juragan' baru bagi Bank Muamalat. Melansir dari www.kompas.com, gagalnya PT Minna Padi mengakuisisi Bank Muamalat Indonesia dikarenakan berakhirnya conditional share subscription aggreement (CSSA) yang berakhir sejak 31 Desember 2017 . $^{7}$

Sebagai bank syariah pertama di Indonesia, seharusnya Bank Muamalat Indonesia berada pada posisi yang lebih baik dibandingkan dengan bank syariah lainnya. Berdasarkan hal tersebut penulis tertarik melakukan penelitian ini.

\section{LANDASAN TEORI}

1. Pengertian Sharia Conformity and Profitability (SCnP) Model

Sharia Conformity and Profitability (SCnP) Model merupakan salah satu model penilaian kinerja keuangan pada perbankan, khususnya pada perbankan syariah. Model SCnP yang akan digunakan merupakan model penilaian kinerja keuangan perbankan syariah yang telah dilakukan oleh Kuppusamy, Saleh, dan Samudhram pada tahun 2010. Model ini menggabungkan orientasinya pada indikator profitabilitas yang digunakan untuk menilai kinerja keuangan konvensional dengan orientasi indeks kesesuaian terhadap sistem syariah untuk menilai sosio-ekonomi kewajiban bank syariah. ${ }^{8}$

2. Indikator SCnP Model

Sharia Conformity and Profitability (SCnP) Model dalam penelitian ini, menggunakan dua indikator, yaitu Sharia Conformity dan Profitability. Sharia Conformity atau kesesuaian syariah akan mengukur seberapa besar bank mampu memenuhi kesesuaiannya dengan sistem syariah, apakah investasinya, pendapatannya, maupun bagi hasilnya

\footnotetext{
${ }^{7}$ Diakses dari https://accuratelite.id/bank-muamalat/pada tanggal 1 Maret 2019.

${ }^{8}$ Muhammad Al Ghifari, Luqman Hakim Handoko, Endang Ahmad Yani.Analisis Kinerja Perbankan Syariah di Indonesia dan Malaysia dengan Pendekatan Maqasid Indeks.Jurnal Ekonomi dan Perbankan.3 (2) 2015. 53.
} 
menggunakan sistem syariah atau belum, sedangkan Profitability atau profitabilitas akan mengukur seberapa besar bank syariah mampu memberikan keuntungan atau labanya selama periode tertentu, dengan mengelola usahanya dalam periode tertentu. ${ }^{9}$

a. Sharia Conformity

Sharia Conformity dapat diukur dengan menggunakan indikator berikut:

1) Investasi Syariah

Berdasarkan hukum Islam, Investasi syariah adalah aktivitaspenempatan dana yang tidak mengandung perbuatan "maysir", "gharar" dan"riba" pada sebuah aset atau lebih. Dalam perbankan syariah di Indonesia tidak bisa dipungkiri bahwa asal usul dari suatu bank syariah adalah rata-rataberasal dari bank konvensional. Sehingga tidak menutup kemungkinan bahwa modal ataupun investasi yang dilakukan bank syariah juga ditempatkan pada bank konvensional sebagai bentuk kelancaran operasional kerja bank yang sewaktu-waktu dibutuhkan. Akun pada laporan keuangan bank syariah yang mengatur hal tersebut berada pada akun Penempatan pada bank lain atau Giro pada bank lain. $^{10}$

Adapun untuk menghitung Investasi Syariah pada perbankan syariah adalah dengan membandingkan Islamic Investment dengan Islamic Investment ditambah dengan NonIslamic Investment. ${ }^{11}$

2) Pendapatan Syariah

Pendapatan syariah adalah pendapatan bagi hasil yang diperoleh bank dengan pembiayaan yang dikeluarkan atau disalurkan bank syariahyang diharapkan dapat mendapatkan hasil. Dalam laporan keuangan bank syariah terdapat akun dana non halal atau pendapatan non halal yang berasal dari sumber dana kebajikan. Dana nonhalal adalah sumber dana kebajikan yang

\footnotetext{
${ }^{9}$ Lia Anggraeni Prasetyowati, Luqman Hakim Handoko.Pengukuran Kinerja Bank Umum Syariah dengan Maqasid Index dan Syariah Conformity and Profitability (SCNP)".Jurnal Akuntansi dan Keuangan Islam.4 (2) 2016. 115.

${ }^{10}$ Iin Afriani Risda. Analisis Kinerja Keuangan Bank Syariah dengan Model Risk Based Banking Rating dan Syaria Conformity and Profiyability (SCnP) Model di Indonesia Periode 2013-2015. Skripsi. (Makassar: Universitas Hasanuddin. 2016). 28.

${ }^{11}$ Ibid., 29.
} 
berasal dari transaksi bank syariah dengan pihak lain yang tidak menggunakan sistem syariah. Dalam hal ini bunga yang diterima tersebut tidak diperbolehkan untuk menambah pendapatan syariah, tetapi dimasukkan sebagai dana kebajikan. ${ }^{12}$

Adapun untuk mengetahui seberapa besar pendapatan syariah pada perbankan syariah maka digunakan Islamic Income dengan membandingkan Islamic Income dengan Islamic Income digabung dengan Non-Islamic Income atau pendapatan non halal. $^{13}$

3) Rasio Bagi Hasil

Rasio bagi hasil yaitu membandingkan kegiatan mudharabah dan musyarakah dengan total pembiayaan yang dilakukan. Indikator rasio bagi hasil menunjukkan seberapa jauh bank syariah dapat membagi hasil keuntungannya kepada para investor. $^{14}$

b. Profitability

Dalam SCnP Model, pengukuran terhadap kinerja keuangan dikukur dengan salah satu indikator keuangan yaitu profitabilitas (profitability). Profitabilitas bank dapat diukur dengan menggunakan indikator berikut:

1) Return On Asset (ROA), yaitu membandingkan pendapatan bersih dengan rata-rata total aset untuk mengukur sejauh mana asset perusahaan bisa menghasilkan laba perusahaan.

2) Return On Equity (ROE), yaitu membandingkan pendapatan bersih dengan modal investor untuk mengukur sejauh mana modal perusahaan bisa menghasilkan laba perusahaan.

3) Profitmargin, yaitu dengan membandingkan pendapatan bersih dengan pendapatan yang diterima untuk mengetahui seberapa besar pendapatan riilyang diterima oleh perusahaan. ${ }^{15}$

\footnotetext{
12 Ibid., 30.

${ }^{13}$ Ibid., 31.

${ }^{14}$ Meri Diana Putri, “Analisis Pengukuran Kinerja Keuangan Bank Syariah Dengan Model Syaria Conformity and Profiyability (SCnP) Model, Sripsi, (UIN Raden Intan Lampung, 2018), h. 35.

${ }^{15}$ Iin Afriani Risda, “Analisis Kinerja Keuangan Bank..............., h. 30
} 
c. Klasifikasi SCnP Model

Berikut adalah model Sharia Conformity and Profitability $(\mathrm{SCnP})$.

Gambar 1. Model SCnP ${ }^{16}$

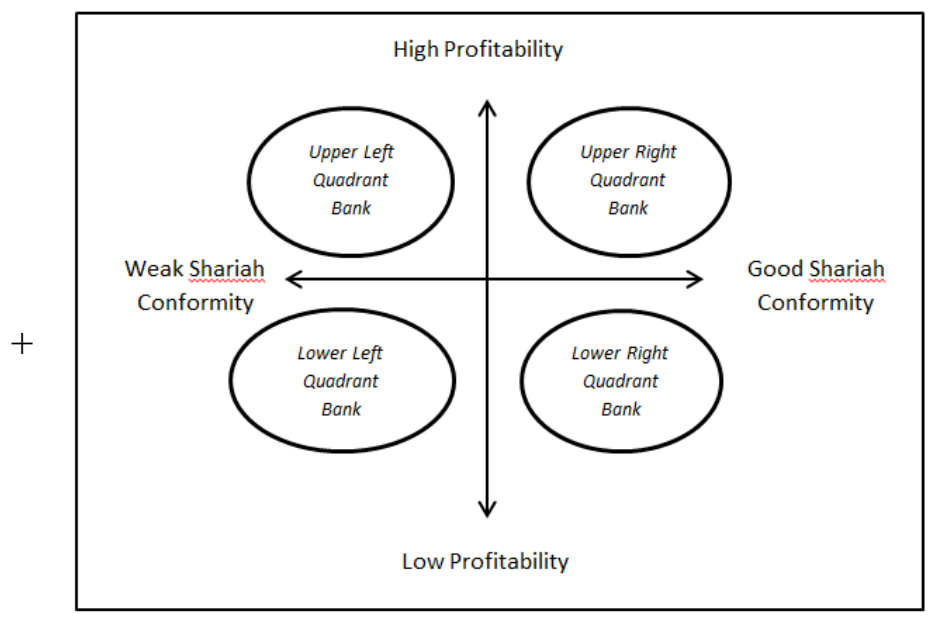

\section{METODOLOGI}

1. Jenis Penelitian

Penelitian ini merupakan penelitian kuantitatif dengan pendekatan studi deskriptif. Tujuannya adalah membuat pencandraan secara sistematis, faktual dan akurat menganai fakta-fakta. ${ }^{17}$ Metode kuantitatif untuk studi deskriptif yang digunakan pada penelitian ini menggunakan metode angka indeks (index number).

2. Sumber Data

Data yang digunakan dalam penelitian ini adalah data sekunder. Data sekunder yang digunakan berupa laporan keuangan tahunan (annual report) PT Bank Muamalat Indonesia Tbk periode 2013-2017 yang diunduh dari official website Bank Muamalat Indonesia.

3. Teknik Pengumpulan Data

Teknik pengumpulan data yang digunakan dalam penelitian ini adalah teknik dokumentasi. Data yang diambil dalam penelitian ini adalah data sekunder yang berasal dari publikasi laporan keuangan tahunan Bank

\footnotetext{
${ }^{16}$ Kuppusamy, Saleha, Samudhram, "Measurement of Islamic Banks Performance using a Sharia conformity and Profitability Model", Review of Islamic Economics, Vol. 13, No. 2. (Leicester: Kube Publishing Ltd Islamic Foundation, 2010),

17 Amos Neolaka, Metode Penelitian dan Statistik, (Bandung: Remaja Rosdakarya, 2014), h. 21
} 
Muamalat Indonesia periode 2013-2017 yang diperoleh dari website resmi PT Bank Muamalat Indonesia Tbk yaitu www.bankmuamalat.co.id.

4. Metode Analisis Data

Metode analisis data yang digunakan dalam penelitian ini adalah menggunakan metode RGEC dan SCnP dengan aplikasi Microsoft Excel dan SPSS 22. Adapun tolak ukur untuk menentukan tingkat kesehatan suatu bank setelah dilakukan penilaian terhadap masing-masing variabel, yaitu dengan menentukan hasil penelitian yang digolongkan menjadi peringkat kesehatan bank. Cakupan penilaian metode SCnP meliputi: Sharia Conformity dan Profitability.

a. Indikator Syaria Conformity

1) Investasi Syariah

Menunjukkan presentase dari investasi yang dilakukan bankpadaproduk halal. Investasi syariah dapat dihitung dengan rumus :

2) Pendapatan Syariah

$$
\text { Investasi Syariah }=\frac{\text { Investasi } \text { Syariah }}{\text { Total Investasi }}
$$

Indikator yang menunjukkan presentase dari seberapa banyak pendapatan halal yang didapatkan dibandingkan dengan total pendapatan yan diperoleh bank. Pendapatan syariah dapat dihitung dengan rumus :

$\frac{\text { Pendapatan Halal }}{\text { Pedapatan Halal + Pendapatan Non Halal }}$

3) Rasio Bagi Hasil

Indikator yang menunjukkanseberapa jauh bank syariah dapat membagihasil keuntungannya kepada para investor. Rasio bagi hasil dapat dihitung dengan rumus:

Pembiayaan Mudharabah dan Musyarakah

Total Pembiayaan

b. IndikatorProfitability

1) Return on Assets (ROA)

Indikator yang umum yang digunakan untuk mengukur kinerja dimana rasio ini menunjukkan perbandingan atau rasio antara rata-rata total aset, dan pendapatan sebelum dan sesudah pajak, dihitung dengan rumus:

$$
\text { ROA }=\frac{\text { Laba Bersih }}{\text { Total Aset }}
$$


2) Return on Equity (ROE)

Indikator yang membagi pendapatan bersih dengan modal pemegang saham yang ada, dihitung dengan rumus:

3) Profit Margin

$$
\mathrm{ROE}=\frac{\text { Laba Bersih }}{\text { Total Ekuitas }}
$$

Indikator yang dihitung dengan membagi keuntungan dengan total pendapatan operasional yang ditunjukkan dalam persentase dari total operasional, dihitung dengan rumus:

Profit Margin Ratio $=\frac{\text { Laba Bersih }}{\text { Total Pendapatan Operasiona } 1}$

Pengukuran kinerja keuangan bank syariah berdasarkan model SCnP dapat dijabarkan dalam tahap-tahap berikut:

a) Menghitung rasio-rasio yang terdapat dalam variabel $\mathrm{SCnP}$.

b) Menghitung rata-rata dari setiap variabel, dengan rumus sebagai berikut:

$$
\bar{X} \mathrm{SC}=\frac{\mathrm{R} 1+\mathrm{R} 2+\mathrm{R} 3}{3}, \bar{X} \mathrm{P}=\frac{\mathrm{R} 1+\mathrm{R} 2+\mathrm{R} 3}{3}
$$

Dimana: $\bar{X} \mathrm{SC}$ rata- rata rasio variabel sharia conformity; $\bar{X} \mathrm{P}$ rata- rata rasio variabel profitability.Variabel $\bar{X} \mathrm{SC}: \mathrm{R} 1$; rasio investasi syariah, R2; rasio pendapatan syariah, R3; rasio bagi hasil. Variabel $\bar{X} \mathrm{P}: \mathrm{R} 1$; rasio return on assets (ROA), $\mathrm{R} 2$; rasio return on equity (ROE), R3; rasio profit margin.

Rata-rata $\bar{X}$ SC akan dijadikan sebagai titik pada kordinat $\mathrm{X}$ (Sharia Conformity) dan rata-rata $\bar{X} \mathrm{P}$ akan dijadikan sebagai titik pada kordinat Y (Profitability).

c. Membuat grafik SCnP dan menginterpretasi sesuai teori.

Ketentuan dalam menempatkan posisi bank sampel pada analisis hasil penelitian SCnP model ditentukan sebagai berikut:

1) Jika hasil akumulasi indikator Sharia Conformity dan Profitability menunjukkan hasil positif ( $>0$ ), maka terletak pada kuadran URL (Upper Right Quadrant Bank).

2) Jika hasil akumulasi indikator Sharia Conformity tinggi dan Profitability yang rendah, maka terletak pada kuadran LRQ (Lower Right Quadrant Bank). 
$178\}\{$ Pengukuran Kinerja Keuangan Bank Muamalat Indonesia

3) Jika hasil akumulasi indikator Sharia Conformity rendah dan Profitability tinggi, maka terletak pada kuadran ULQ (Upper Left Quadrant Bank).

4) Jika hasil akumulasi indikator Sharia Conformity dan Profitability menunjukkan hasil yang negatif, maka terletak pada kuadran LLQ (Lower Left Quadrant Bank).

\section{PEMBAHASAN}

\section{Sharia Conformity}

Sharia Conformity atau ketaatan syariah akan mengukur seberapa besar bank mampu memenuhi kesesuaiannya dengan sistem syariah, apakah investasinya, pendapatanya maupun bagi hasilnya menggunakan sistem syariah atau belum. Sharia Conformity menggunakan tiga aspek dalam pengukurannya yaitu investasi syariah, pendapatan Syariah dan Rasio Bagi Hasil.

a) Investasi Syariah

Berdasarkan hukum islam, investasi syariah adalah aktivitas penempatan dana yang tidak mengandung perbuatan maysir, gharar dan riba pada sebuah asset atau lebih.

Tabel 1. Investasi Syariah (Dalam Ribuan Rupiah)

\begin{tabular}{|c|c|}
\hline Tahun & Investasi Syariah \\
\hline 2013 & 3.583 .882 .552 \\
\hline 2014 & 4.922 .225 .165 \\
\hline 2015 & 4.504 .593 .754 \\
\hline 2016 & 3.831 .311 .720 \\
\hline 2017 & 3.820 .521 .866 \\
\hline
\end{tabular}

Sumber: Data diolah.

Selanjutnya pada penelitian ini tidak ditemukan adanya kegitan Non-Islamic Investment pada perbankan syariah maka rasio Islamic Investment pada Bank Muamalat Indonesia periode 2013-2017 adalah sebagai berikut:

Tabel 2. Rasio Investasi Syariah

\begin{tabular}{|c|c|}
\hline Tahun & Rasio Investasi Syariah \\
\hline 2013 & $100 \%$ \\
\hline 2014 & $100 \%$ \\
\hline 2015 & $100 \%$ \\
\hline
\end{tabular}




\begin{tabular}{|l|l|}
\hline 2016 & $100 \%$ \\
\hline 2017 & $100 \%$ \\
\hline
\end{tabular}

Sumber: Data diolah, 2019

Dari data di atas secara keseluruhan Bank Muamalat Indonesia melakukan investasi di sektor syariah dan tidak ada investasi non syariah. Kondisi ini menggambarkan Bank Muamalat Indonesia menerapkan prinsip syariah dalam kegiatan investasinya.

b) Pendapatan Syariah

Pendapatan syariah adalah pendapatan bagi hasil yang diperoleh bank dengan pembiayaan yang dikeluarkan atau disalurkan bank syariah yang diharapkan dapat mendapatkan hasil atau keuntungan.

Tabel 3. Islamic Income (Dalam Ribuan Rupiah)

\begin{tabular}{|c|c|}
\hline Tahun & Pendapatan Halal \\
\hline 2013 & 2.553 .462 .300 \\
\hline 2014 & 2.176 .139 .359 \\
\hline 2015 & 2.407 .359 .371 \\
\hline 2016 & 1.823 .536 .285 \\
\hline 2017 & 1.644 .633 .347 \\
\hline
\end{tabular}

Sumber: Data diolah, 2019

Selanjutnya Non Islamic Income BMI tahun 2013-2017 disajikan sebagai berikut:

Tabel 4. Non-Islamic Income (Dalam Ribuan Rupiah)

\begin{tabular}{|c|c|}
\hline Tahun & Pendapatan Non Halal \\
\hline 2013 & 2.579 .259 \\
\hline 2014 & 3.973 .950 \\
\hline 2015 & 5.689 .577 \\
\hline 2016 & 1.303 .379 \\
\hline 2017 & 881.896 \\
\hline
\end{tabular}

Sumber: Data diolah, 2019

Dari beberapa data diatas dihasilkan Islamic Income Ratio sebagai berikut:

Tabel 5. Rasio Pendapatan Syariah

\begin{tabular}{|c|c|}
\hline Tahun & $\frac{\text { PendapatanHalal }}{n}$ \\
\hline 2013 & $99,89 \%$ \\
\hline
\end{tabular}


$180\}\{$ Pengukuran Kinerja Keuangan Bank Muamalat Indonesia

\begin{tabular}{|l|l|}
\hline 2014 & $99,81 \%$ \\
\hline 2015 & $99,76 \%$ \\
\hline 2016 & $99,92 \%$ \\
\hline 2017 & $99,94 \%$ \\
\hline
\end{tabular}

Sumber: Data diolah.

Dari data diatas terlihat bahwaBank Muamalat Indonesia memiliki persentase Islamic Income yangfluktuatif. Tahun 2017 merupakan tahun dengan Rasio Pendapatan Syariah tertinggi, sedangkan rasio terrendah pada tahun 2015.

c) Rasio Bagi Hasil

Rasio Bagi Hasil menunjukkan seberapa jauh bank syariah dapat membagi hasil keuntungannya kepada investor dengan membandingkan mudharabah dan musyarakah dengan jumlah pembiayaan pada bank syariah.

Tabel 6. Pembiayaan Musyarakah dan Mudharabah

(Dalam Ribuan Rupiah)

\begin{tabular}{|c|c|c|}
\hline Tahun & $\begin{array}{c}\text { Pembiayaan } \\
\text { Mudharabah }\end{array}$ & $\begin{array}{c}\text { Pembiayaan } \\
\text { Musyarakah }\end{array}$ \\
\hline 2013 & 2.170 .219 .003 & 17.855 .906 .306 \\
\hline 2014 & 1.723 .618 .638 & 19.549 .525 .035 \\
\hline 2015 & 1.052 .718 .497 & 20.192 .427 .340 \\
\hline 2016 & 794.219 .700 & 20.125 .269 .223 \\
\hline 2017 & 703.554 .231 & 19.160 .884 .745 \\
\hline
\end{tabular}

Sumber: Data diolah.

Tabel 7.Jumlah Pembiayaan (Dalam Ribuan Rupiah)

\begin{tabular}{|c|c|}
\hline Tahun & Total Pembiayaan \\
\hline 2013 & 41.612 .000 .000 \\
\hline 2014 & 42.865 .000 .000 \\
\hline 2015 & 40.706 .000 .000 \\
\hline 2016 & 40.010 .000 .000 \\
\hline 2017 & 41.288 .000 .000 \\
\hline
\end{tabular}

Sumber: Data diolah.

Berdasarkan data di atas maka menghasilkan Profit Sharing Ratio Bank Muamalat Indonesia tahun 2013-2017 sebagai berikut: 
Tabel 8. Rasio Bagi Hasil

\begin{tabular}{|c|c|}
\hline Tahun & $\frac{\text { PembiayaanMudharabah }+ \text { Musyarakah }}{}$ \\
\hline 2013 & TotalPembiayaan \\
\hline 2014 & $48,12 \%$ \\
\hline 2015 & $49,62 \%$ \\
\hline 2016 & $52,19 \%$ \\
\hline 2017 & $52,28 \%$ \\
\hline
\end{tabular}

Sumber: Data diolah.

Presentase Profit Sharing Ratio Bank Muamalat Indonesia mengalami kenaikan selama empat tahun berturut-turut, dari tahun 2013 sampai dengan tahun 2016.Hal ini menunjukkan bahwa BMI semakin baik dalam membagi keuntungan yang diperoleh dengan proporsi masing-masing investor serta keuntungan dan kerugian ditanggung bersama.Pada tahun 2017 persentase Rasio Bagi Hasil mengalami penurunan sebesar $4,17 \%$ dari tahun sebelumnya.

2. Profitability

Profitabilitas pada SCnP Model menggunakan tiga indikator didalamnya yaitu Return On Asset (ROA), Return On Equity (ROE) dan Profit Margin Ratio.

a. Return On Asset (ROA)

Return On Assets digunakan untuk mengukur kemampuan manajemen bank dalam memperoleh laba secara keseluruhan. Semakin besar ROA suatu bank, maka seakin besar pula tingkat keuntungan yang dicapai bank tersebut dan semakin baik pula posisi bank tersebut dari segi penggunaan asset. Rasio ini diukur dengan membandingkan Laba Bersih dengan total asset yang dimiliki bank.

Tabel 9. Laba Bersih (Dalam Ribuan Rupiah)

\begin{tabular}{|c|c|}
\hline Tahun & Laba Bersih (Net Income) \\
\hline 2013 & 165.144 .318 \\
\hline 2014 & 57.173 .347 \\
\hline 2015 & 74.492 .188 \\
\hline 2016 & 80.511 .090 \\
\hline 2017 & 26.115 .563 \\
\hline
\end{tabular}

Sumber: Data diolah. 
Tabel 10. Total Asset (Dalam Ribuan Rupiah)

\begin{tabular}{|c|c|}
\hline Tahun & Total Asset \\
\hline 2013 & 53.723 .978 .628 \\
\hline 2014 & 62.413 .310 .135 \\
\hline 2015 & 57.172 .587 .967 \\
\hline 2016 & 55.786 .397 .505 \\
\hline 2017 & 61.696 .919 .644 \\
\hline
\end{tabular}

Sumber: Data diolah.

Berdasarkan data di atas, berikut adalah hasil pengukuran Return On Assets (ROA) yang didapat:

Tabel 11. Return On Assets (ROA)

\begin{tabular}{|c|c|c|c|c|}
\hline \multicolumn{5}{|c|}{ Tahun } \\
\hline 2013 & 2014 & 2015 & 2016 & 2017 \\
\hline $0,3 \%$ & $0,09 \%$ & $0,13 \%$ & $0,14 \%$ & $0,04 \%$ \\
\hline
\end{tabular}

Sumber: Data diolah.

Berdasarkan hasil perhitungan ROA BMI pada tahun 20132017 menunjukkan kemampuan bank dalam mendapatkan return terhadap pengelolaan Assets tidak cukup memuaskan, sesuai dengan standar kreteria penilaian yang dikeluarkan oleh bank Indonesia dan Otoritas Jasa Keuangan sebesar 1,22\%. Artinya selama 5 tahun berada pada predikat tidak baik dan kurang baik.

b. Return On Equity (ROE)

Return On Equity adalah pengukuran yang menunjukkan kemampuan bank dalam menghasilkan keuntungan dari pengelolaan ekuitas yang dimiliki oleh bank. ROE didapatkan dengan membandingkan laba bersih dan total ekuitas yang dimiliki oleh bank.

Tabel 12. Ekuitas (Dalam Ribuan Rupiah)

\begin{tabular}{|c|c|}
\hline Tahun & Ekuitas \\
\hline 2013 & 3.321 .206 .899 \\
\hline 2014 & 4.023 .951 .885 \\
\hline 2015 & 3.550 .563 .883 \\
\hline 2016 & 3.618 .746 .556 \\
\hline 2017 & 5.545 .366 .904 \\
\hline
\end{tabular}

Sumber: Data diolah. 
Ekuitas merupakan unsur kepemilikan atau kekayaan para pemegang saham yang menanamkan sahamnya dalam sebuah intansi atau perusahaan. Ekuitas yang besar menunjukkan seberapa besar jumlah yang diinvestasikan para pemegang saham. Data diatas menunjukkan bahwa ekuitas BMI selama 5 tahun bersifat fluktuatif.

Dari beberapa data diatas maka nilai ROE pada Bank Muamalat Indonesia tahun 2013-2017 sebagai berikut:

Tabel 13. Return OnEquity(ROE)

\begin{tabular}{|c|c|c|c|c|}
\hline \multicolumn{5}{|c|}{ Tahun } \\
\hline 2013 & 2014 & 2015 & 2016 & 2017 \\
\hline $4,97 \%$ & $1,42 \%$ & $2,09 \%$ & $2,22 \%$ & $0,47 \%$ \\
\hline
\end{tabular}

Sumber: Data diolah.

c. Profit Margin Ratio

Profit Margin Ratio merupakan kemampuan bank dalam menghasilkan laba dari kegiatan operasional bank.Profit Margin diukur dengan membandingkan laba bersih dengan total pendapatan bank.

Tabel 14. Profit Margin Ratio

\begin{tabular}{|c|c|c|c|c|}
\hline \multicolumn{5}{|c|}{ Tahun } \\
\hline 2013 & 2014 & 2015 & 2016 & 2017 \\
\hline $6,46 \%$ & $2,62 \%$ & $3,09 \%$ & $4,41 \%$ & $1,58 \%$ \\
\hline
\end{tabular}

Sumber: Data diolah.

Dari data di atas Rasio Profit MarginBank Muamalat Indonesia dari tahun 2013 sampai dengan 2017 bersifat fluktuatif. Pada tahun 2014 mengalami penurunan persentase yang cukup signifikan dari tahun sebelumya sebesar 3,84\%. Sedangkan dari tahun 2014 sampai dengan 2016 secara berturut-turut mengalami penurunan. Pada tahun 2017 mengalami penurunan prensentase Profit Marginyang cukup signifikan dari 4,41\% menjadi 1,58\%. Penurunan ini dikarenakan adanya penurunan laba bersih dan meningkatnya biaya yang harus ditanggung oleh bank yang tidak diiringi peningkatan pendapatan operasional.

Selanjutnya, dari hasil perhitungan masing-masing indikator di atas akan diolah lagi untuk nilai rata-rata yang akan dijadikan sumbu $\mathrm{X}$ dan sumbu $\mathrm{Y}$ yang nantinya akan menentukan posisi kuadran. Berikut ini tabel pengolahan data masing-masing indikator. 
$184\}$ \{ Pengukuran Kinerja Keuangan Bank Muamalat Indonesia

Tabel 15. Perhitungan Indikator Syaria Conformity (\%)

\begin{tabular}{|c|c|c|c|c|}
\hline Tahun & $\mathrm{R} 1$ & $\mathrm{R} 2$ & $\mathrm{R} 3$ & $\frac{\mathrm{R} 1+\mathrm{R} 2+\mathrm{R} 3}{3}$ \\
& & & $\bar{X} \mathrm{SC})$ \\
\hline 2013 & 100 & 99,89 & 48,12 & 82,67 \\
\hline 2014 & 100 & 99,81 & 49,62 & 83,14 \\
\hline 2015 & 100 & 99,76 & 52,19 & 83,98 \\
\hline 2016 & 100 & 99,92 & 52,28 & 84,06 \\
\hline 2017 & 100 & 99,94 & 48,11 & 82,68 \\
\hline
\end{tabular}

Sumber: Data diolah.

Tabel16. Perhitungan Indikator Profitability (\%)

\begin{tabular}{|c|c|c|c|c|}
\hline Tahun & $\mathrm{R} 1$ & $\mathrm{R} 2$ & $\mathrm{R} 3$ & $\frac{\mathrm{R} 1+\mathrm{R} 2+\mathrm{R} 3}{3}$ \\
\hline 2013 & 0,3 & 4,97 & 6,46 & $\frac{3}{(\bar{X} \mathrm{P})}$ \\
\hline 2014 & 0,09 & 1,42 & 2,62 & 1,37 \\
\hline 2015 & 0,13 & 2,09 & 3,09 & 1,77 \\
\hline 2016 & 0,14 & 2,22 & 4,41 & 2,25 \\
\hline 2017 & 0,04 & 0,47 & 1,58 & 0,69 \\
\hline
\end{tabular}

Sumber: Data diolah.

Dari data di atas, maka langkah selanjutnya adalah menentukan posisi kuadran dengan menggunakan aplikasi SPSS 22. Berikut ini adalah hasil pengolahan data menggunakan SPSS 22.

Gambar 2. Posisi Kuadran

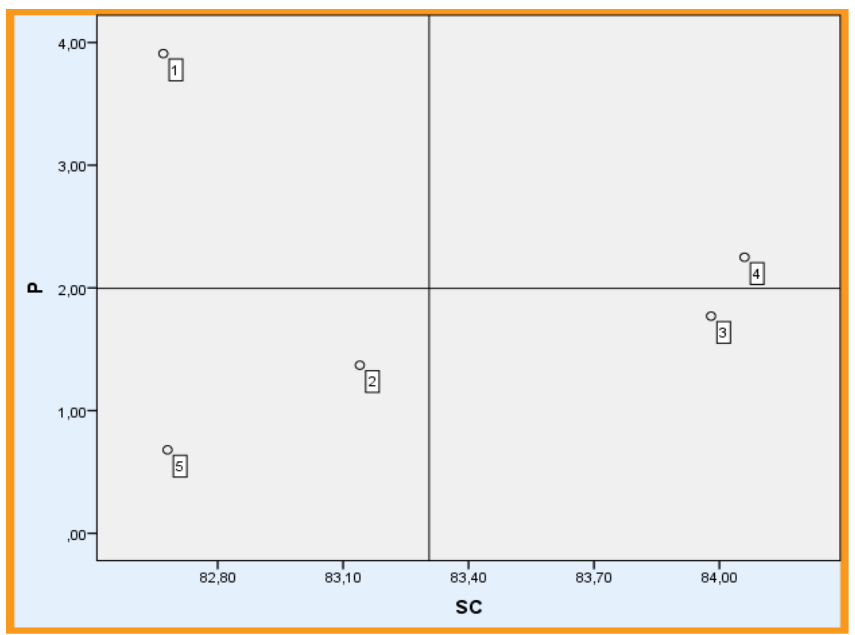

Sumber: Datadiolah menggunakan SPSS 22. 
Keterangan: Angka 1-5;Secara berurutan tahun 2013-2017, SC ;Syaria Conformity, $\mathrm{P}$;Profitability

Pada Grafik SCnP Model di atas, menunjukkan gambaran kinerja Bank Muamalat Indonesia selama lima tahun tersebar dalam 4 kuadran. Hasil penelitian menunjukkan bahwa pada tahun 2013 yang ditujukkan dengan angka 1 berada pada Upper Left Quadrant (ULQ), yang mengindikasikan BMI memiliki tingkat kesesuaian prinsip syariah yang rendah namun profitabilitas yang tinggi. Tahun 2014 dan 2017 yang ditunjukkan dengan angka 2 dan 5 berada pada Lower Left Quadrant (LLQ), yang mengindikasikan bank memiliki tingkat kesesuaian prinsip syariahdan profitabilitas yang rendah. Pada tahun 2015 yang ditujukkan dengan angka 3 berada pada Lower Right Quadrant (LRQ), yang mengindikasikan BMI memiliki tingkat kesesuaian prinsip syariah yang tinggi namun profitabilitas yang rendah. Sedangkan tahun 2016 yang ditujukkan dengan angka 4 berada pada kuadran terbaik yaituUpper Right Quadrant (URQ), yang mengindikasikan BMI memiliki tingkat kesesuaian prinsip syariah dan profitabilitas yang tinggi.

Analisis selama lima tahun menghasilkan beberapa pergerakan yang berbeda-beda. Hal ini dikarenakan kondisi perusahaan, dalam hal ini PT Bank Muamalat Indonesia selama periode 2013-2017 juga mengalami kenaikan dan penurunan yang berbeda-beda.Perubahan jumlah maupun nilai rasio yang dihasilkan dari kegiatan operasional BMI pada umumnya juga mempengaruhi pergerakan posisi bank dalam kuadran. Hal inilah yang akan mempermudah analisis kondisi kinerja keuangan masing-masing periode.

\section{KESIMPULAN}

Hasil penelitian terhadap Bank Muamalat Indonesia tahun 2013-2017 dengan menggunakan Model SCnP secara berturut-turut bank berada pada posisi Upper Left Quadrant (ULQ), Lower Left Quadrant (LLQ), Lower Right Quadrant (LRQ), Upper Right Quadrant (URQ) dan Lower Left Quadrant(LLQ). Hal ini berarti bahwa selama lima tahun posisi bank tersebut dalam empat kuadran dengan perolehan nilai berbeda beda. Secara garis besar bank berada di sebelah kiri garis X dan di bawah garis $\mathrm{Y}$ yang berarti kesesuaian prinsip syariah dan profitabilitas BMI rendah. Dengan 
hasil demikian, dapat ditarik kesimpulan bahwa hasil penelitian ini terdapat relevansi dengan apa yang sedang terjadi pada BMI.

\section{DAFTAR PUSTAKA}

Al Ghifari, Muhammad dkk. 2016. Analisis Kinerja Perbankan Syariah Di Indonesia dan Malaysia dengan Pendekatan Maqasid Indeks. Jurnal Ekonomi Dan Perbankan. 3 (2).

Neolaka, Amos. 2014. Metode Penelitian dan Statistik, Bandung: Remaja Rosdakarya.

Aolia, Annisa Dina. 2017. Analisis Penilaian Kinerja Perbankan Syariah Di Indonesia Menggunakan Metode RGEC dan Sharia Maqashid Index, Skripsi. Jakarta: UIN Syarif Hidayatullah

Dwi, Muhammad Suwiknyo. 2009. Akuntansi Perbankan Syariah. Yogyakarta: Trust Media.

Ismail. 2011. Perbankan Syariah. Jakarta: Kencana Prenada Group.

Muchtar, Evan Hamzah. 2018. Konsep Hukum Bisnis Syariah Dalam A1Qur'an Surah Al-Baqarah [2] Ayat 168-169 (Kajian Tematis Mencari Rezeki Halal), Ad-Deenar: Jurnal Ekonomi dan Bisnis Islam, 2 (2). 156.

Mudiarasan Kuppusamy, Ali Salman Saleha, dan Ananda Samudhram. 2010. "Measurement of Islamic Banks Performance Using a Sharia conformity and Profitability Model", Review of Islamic Economics, Vol. 13, No. 2. (Leicester: Kube Publishing Ltd Islamic Foundation, $35-48$

Prasetyowati, Lia Anggraeni dan Luqman Hakim Handoko. 2016. Pengukuran Kinerja Bank Umum Syariah dengan Maqasid Index dan Syariah Conformity and Profitability (SCnP). Jurnal Akuntansi dan Keuangan Islam. 4 (2). 109.

Putri, Meri Diana. 2018. Analisis Pengukuran Kinerja Keuangan Bank Umum Syariah di Indonesia Menggunakan Metode Sharia Conformity and Profitability (SCnP) Model, Skripsi. Lampung: UIN Raden Intan.

Risda, Iin Afriani. 2016. Analisis Kinerja Keuangan Bank Syariah dengan Model Risk Based Banking Rating dan Syaria Conformity and Profiyability (SCnP) Model di Indonesia Periode 2013-2015.Skripsi. Makassar: Universitas Hasanuddin.

https://accuratelite.id/bank-muamalat/ Diakses dariwww.bankmuamalat.co.id. 